\title{
MUSICAL CONTENT INSPIRED BY NATIONAL CREATIVITY OF ETHNIC COMMUNITIES OF VOJVODINA - MODELS OF MUSIC ABILITY DEVELOPMENT AT THE PRESCHOOL AGE
}

\author{
Eudjen CINC, Ph.D \\ West University Timisoara - Faculty of Music and Theatre \\ eugencinci@gmail.com
}

\begin{abstract}
It is undeniable that tradition and culture form a nation's "mirror of the soul". In accordance with this the cultural heritage of a country with all its elements is the reflection of the existence of every nation (Stolic, 2017:182). It is clear to everyone that the young are the successors and carriers of the nation's cultural identity, but it is also well known that children cannot often come across and in that way learn about the cultural heritage of their country. The way of dressing and life is different today and traditional songs and games are rarely listened to and performed (Stolic, 2017:182). Therefore, it is necessary to periodically influence and enrich their lives with traditional national songs and games. National songs and games with singing can be present in the children's lives from their birth. Through an adequate selection and usage the children will in an unobtrusive way become familiar with their national heritage through song and play (Stolic, 2017). The topics of national song and games can be diverse, but humorous and love texts are the most common. Also common are the texts which describe work in the fields or the process of other types of work.
\end{abstract}

Key words: cultural heritage; models of music;song and games

\section{Methodic actions}

Depending on the selection of the song or game with singing, the preschool teachers need to make an adequate atmosphere. They need to familiarize the children with the origin of the song or game. Firstly they can familiarize the children with: significant historic information and characteristics of the nation that produced the song, how the song or game was created, at what occasions it is performed, the way in which the people who made the song dressed and lived at the time when the song or game were created, and many other facts (Pavlić-Mandić, 1979: 5-6). For the children to become more involved the preschool teachers need to familiarize the things which are usually unknown to them. It would be desirable to equip the classroom in the spirit of the people's daily lives, also the costum that follows the given song or game, e.g, to show them as many elements, pictures, items, clothes, shoes and other things as possible. If there's a possibility, the preschool teacher can wear appropriate clothes, i.e. traditional clothing that was worn back then. In regard to what was mentioned, it is necessary to think of a motivational preparation as an introduction to the methodical articulation of the activity. The introduction part of the activity serves as an emotional preparation within which a certain feeling is made and awakes interest in children. (Đurković-Pantelić, 1998:105).

The motivational preparation is followed by a learning announcement (ĐurkovićPantelić, 1998:105). To make the task more interesting, an enigmatic question can be asked, e.g., What kind of a miracle has happened in Budim city? In that way, the children can surely actively listen to the teacher's performance so that they could "discover" and find the answer to the asked question, and at the same time "experience" the song. Then comes a short conversation about the happenings in the song and feelings that the children have experienced while listening to the performance. 
After the motivational preparation and demonstration of the song comes the teaching of the song text (Stolic, 2014: 79). Since national song texts contain many words which are unknown to children, they need to be explained and the plot of the song explained (Stolic, 2014: 94). The preschool teacher expressively recites the song in its entirety and then explains the unknown words. The song is taught in segments (Stolic, 2014: 79). The preschool teacher expressively recites the segment at least two times after which the children repeat the same segment a number of times. When the children have learned the first verse in this way, the verse is recited in its entirety by the children. The teaching in segments is repeated for all of the verses (if there is more than one verse) (Stolic, 2014).

The learning of the song text is followed by breathing exercises and voice training exercises which need to be in accordance with the main activity (Durkovic-Pantelic, 1998: 72-84, Cinc, 2012: 53-58, Stolic, 2014: 32-43). For the children to be motivated they need to be implemented through play (Stolic, 2014: 32-43). Firstly we start with breathing exercises. The correct usage of air is founded on diaphragm breathing, which consists of filling the lungs and abdomen with air during the inhaling and emptying during exhaling (Cinc, 2012: 54). During breathing exercises it is necessary to implement exercises for the development of the chest and practice: correct body posture, slow and quick inhaling and exhaling, the way in which we breathe in and hold the breath before singing (so that children could, when the time comes, correctly and confidently produce the singing tone), correct diction and text pronunciation (Stolic, 2014). In this way the children will achieve the ability to evenly and without breaks exhale for a long time, which will contribute to the ease of singing (Ђурковић-Пантелић, 1998). After the breathing exercises come voice training exercises. These exercises are meant to prepare the singing apparatus for singing and warm up the vocal cords. With these exercises we can practice and prepare for a jump in the melody, a specific rhythm figure, the widening of the vice range, practice dynamics, tempo, articulation and many other occurrences in music (Stolic, 2014). Voice training exercises can be organized within everyday activities, for example the preschool teacher asks questions through singing, and children answer in the same way, but also through especially created exercises connected to the topic of the activity (Stolić, Činč, Maran, 2015). The children can for example imitate the sounds of animals or which occur in nature etc. A simple familiar song can be used for this purpose also. At the start songs with three or four tones should be used with the goal to widen the range, latter use exercises on one tone, which are also very demanding because the vocal cords are equally stressed (Stolic, 2014). Of course these exercises also need to be adapted to the children's musical development.

In order to follow the didactic principle of time economy the preschool teacher can think of a story with a game (in accordance with the topic of the activity and selected song or game with singing which is being taught), within which all of the aforementioned exercises will be demonstrated (breathing and voice training). The children need to repeat everything that the preschool teacher does (Stolic, 2014: 141-143). The children will in this way acquire all of the necessary exercises in an interesting way and be ready for singing.

The mentioned exercises are followed by a melody-rhythm interpretation of the song by ear. The procedure of teaching is similar to the teaching of a text and it consists of learning in sections. The teacher sings expressively part of the text (most frequently the first verse) at least twice, then, after listening, for a few times, the children sing the same part. After that they start on the next verse. When they have learned the first verse with this principle, they expressively sing the whole verse (Stolić, 2014). If the song has a few verses, the principle is repeated for each one.

If the verses are hard for the kids to learn, after learning the text of the first verse we immediately teach its melody in order to make sure that the children mastered the song, only 
then can we continue with the second verse. After all of the verses have been taught, the song should be performed as a whole.

It is certain that the process of acquiring folk songs or games with singing is not simple, starting with the right selection of songs and games to be taught to teaching songs and performance of games. It is necessary to spend a lot of time and patience to become familiar with the songs, and to compile the whole methodical preparation for their implementation, starting from the motivational preparation to the conclusion of the activity.

\section{$* * *$}

The area of Vojvodina from the oldest times has represented an area in which many cultures, confessions and languages intertwined. Many peoples crossed its territory, countries with different government orders were formed and disappeared, so we can conclude that it has always represented a model of multiethnic, multicultural and multireligious society. The Ethical picture of modern Vojvodina began to be created in the $18^{\text {th }}$ century, in the period of Habsburg colonization which came after the Ottomans' departure from the area which used to belong to south Hungary. The main motive of the colonization of a large number of different nationalities implemented by the Habsburg Monarchy was of an economic nature. Namely, it was supposed to restore and revive the stagnated economy of the new conquered areas. Furthermore, it was supposed to strengthen the defense on its south border in a situation where the Ottoman empire still represented a serious threat. The second goal was to create an ethical and confessional diverse environment, so if needed, the state could easily manipulate with its citizens, keep the subjects under control and keep the already existing state and social structure, using the politics which was used by Romans called divide et impera.

The Czechs started to settle todays Vojvodina in the $18^{\text {th }}$ and $19^{\text {th }}$ centuries. In 1762 in Backa they settled Bezdan and Kupusina, and in 1827 in Banat 60 Czechs settled Kruscica and Bela Crkva, and in the same year 24 Czech families from the former town of Sental on the Danube settled on a field Albian, in the Atar area, where they received 295 morgens of land. In Veliko Srediste near Vrsac the feudal lord Golub Lazarevic in 1838 built a manour house and in it settled about 30 Czech and Bulgarian families. In the year 1920 in Gaj near Kosovina 20 Check families from Granika settled there. The Czechs in Vojvodina are mostly of the Catholic religion although there are those who are Evangelists. They gave Vojvodina many famous individuals in the area of culture, science and art. Among them were Robert Tolinger (1859-1911) composer and choir-master, Vladislav Titelbah (1847-1925) professor, Dragutin Blazek (1847-1922) choir-master, composer and a music pedagogue, Rudolf Novacek (1860-1929), visual artist, Mihovil Tomandl (1849-1963) lawyer and historian and others.

\section{Suggestion of music examples}

\section{Example. Czech national song Sleen Ancice (Vukomanović, 1984: 55):}

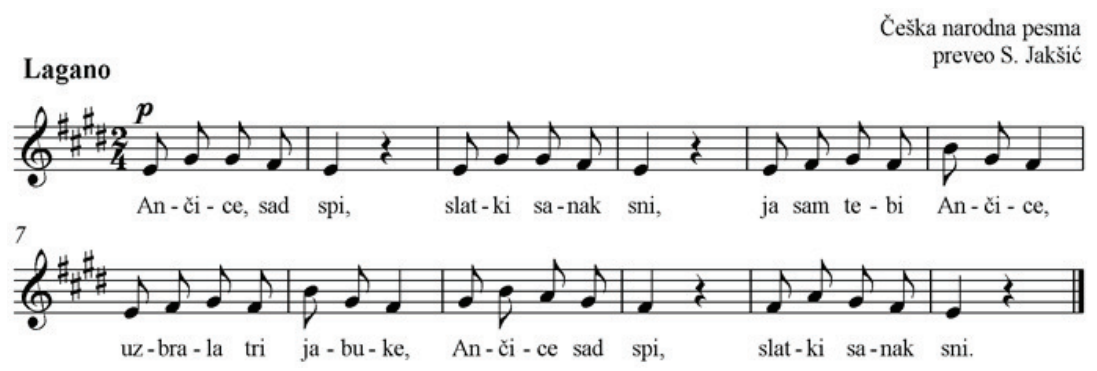


The song is intended to be performed with children of the middle and older group. Since it is a lullaby, it is suitable for the creation of musical and listener notions, and if need be familiarization with the music genre of cantilena, as one of the three main "musical columns" (Kabalevski as cited in Radičeva, 2000: 366).

Example. Czech national song Kdyžjsem šelzhradišt’a(Jánský, 1994: 17):

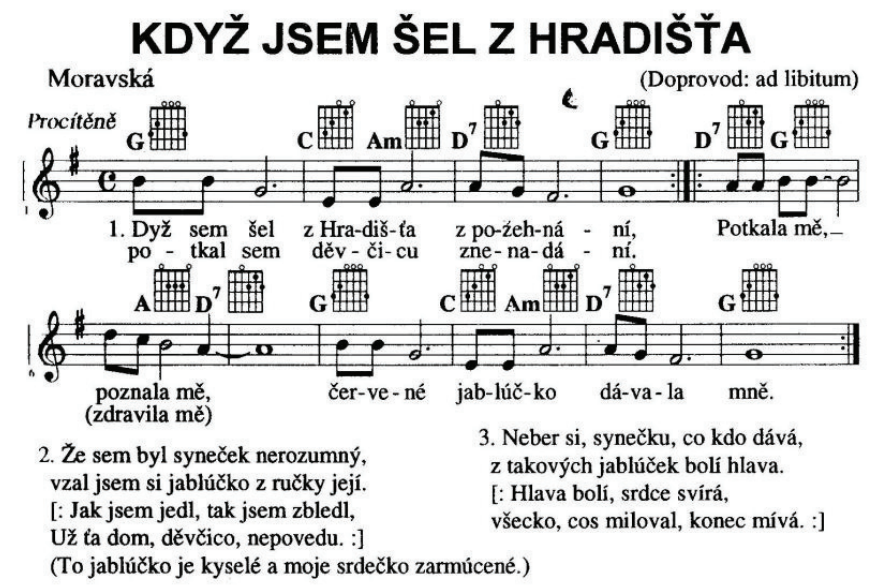

The song is intended to be performed with children of the preoperational group, as well as for younger school aged children. It is characterized by longer note values, therefore it is necessary, for the breath to last, to prepare the children through breathing and voice training exercises.

Example. Czech national song Koline, Koline (Jánský, 1994: 17):

\section{KOLÍNE, KOLÍNE}

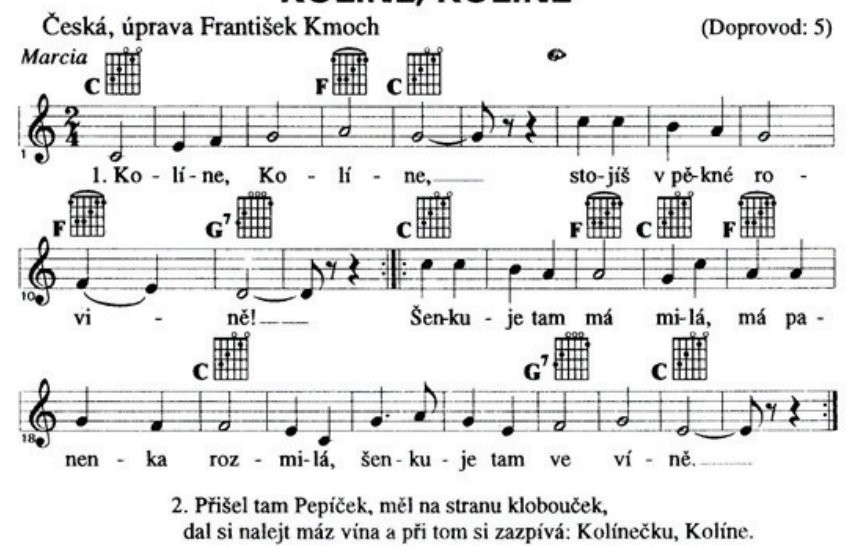

The song is intended to be performed with the children of the older and preparatory preschool group (note: hereinafter the proposed songs are suitable for the young school age). It is characterized by the pace of the march and a two-way measure, thus it is suitable for creating musical and auditory performances, and if necessary it can be used for the development of musical literacy, as well as getting the children familiar with the musical genre of the march, one of the three main "musical pillars" mentioned ( Radiceva, 2000:366). 
The Hungarians moved to the Pannonia Plain at the end of the $9^{\text {th }}$ century under the leadership of Arpad and in the beginning of the $11^{\text {th }}$ century upon they acceptance of Christianity, their ruler Stefan I received the Royal crown from the Roman Pope.

The Hungarian kingdom in the middle ages represented a significant political factor in Europe until it's fall to Ottoman rule in 1541. During the late middle ages, the territory of today's Vojvodina was part of the Hungarian state in which the nobility enjoyed special privileges.

After the defeat of the Hungarian army in battle on Mohac (1526.), the death of king Ludvig II opened the question of the selection of the new king in which the main pretenders were the Duke of Vojvodina Jovan Zapolja and the Habsburg ruler Ferdinand, who imposed himself as the king of the Hungary, and on this basis the Habsburgs, until the collapse of the Austro-Hungarian monarchy along with the imperial title, also held titles of Hungarian kings. The colonization of Hungarians in Banat had progressed slowly, first in its southern parts that were in within Banat's military border, to the Austro-Hungarian settlement from 1867, because the Austrians tried, for political reasons, to prevent the Hungarian to settle. After the resolution in 1867., (with the establishment of a dual monarchy), the ruling Hungarian circles wanted to increase the number of Hungarians living on these territories so the first wave of colonization was achieved from 1860-1890 under very unfavorable conditions for the colonies. On that occasion they were settled, in the surrounding of Pančevo, Skorenovac and Vojlovica with Szekelys from Bukovina.

Today, Hungarians make the majority of the population in municipalities Kanjiža, Senta, Ada, Bačka Topola, Mali Iđoš, Čoka and a relative majority in the municipalities/cities Bečej and Subotica. A big amount of the Hungarian minority lives in other cities and municipalities in Vojvodina (Temerin, Srbobran, Novi Bečej, Novi Sad, Kula).

\section{Suggestion of musical examples}

Example: Hungarian national song (Forrai, 1991:162):

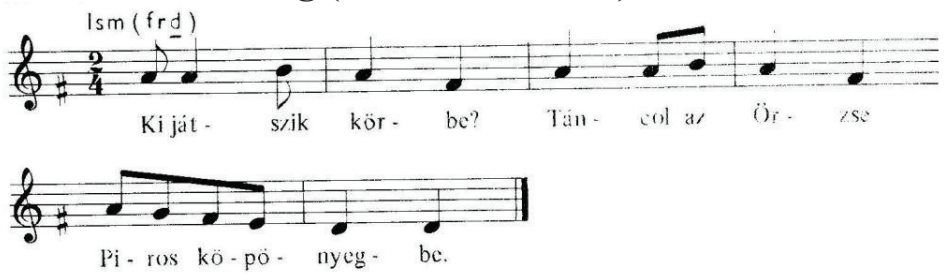

Játékra hívogató

Három-négy gyermek körben jár, és a csatlakozó játszótársakat maguk közé veszik. A dallamot addig ismétlik, míg a további játékokhoz nincsenek elegen.

The song is intended to be performed with children of the middle and older age group. At the beginning there is a specific rhythmic figure - syncope, therefore it is appropriate to use (especially for the beginning of musical literacy).

Example. Hungarian national song (Forrai, 1991: 214):

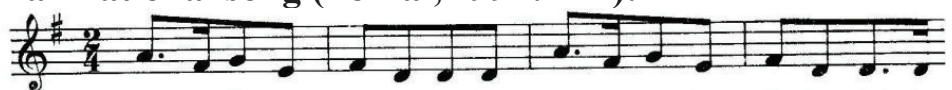

1. Kösd fel Ör-zse, köd-mön-ké-det, Kösd be bog-lyas fe -jecs-ké-dê:

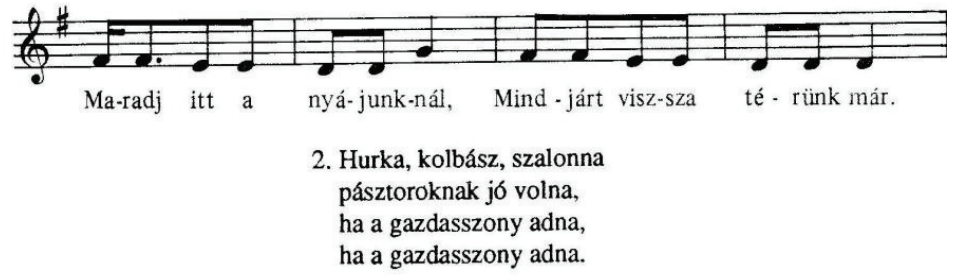


The song is intended to be used with the younger and middle age groups. It is categorized by rhythmic figures - dotted and reverse dotted rhythm on a unit of counting, therefore its purpose is, apart from creating music and auditory representations, to familiarize the children with these music figures.

\section{Example. Hungarian children's song:}

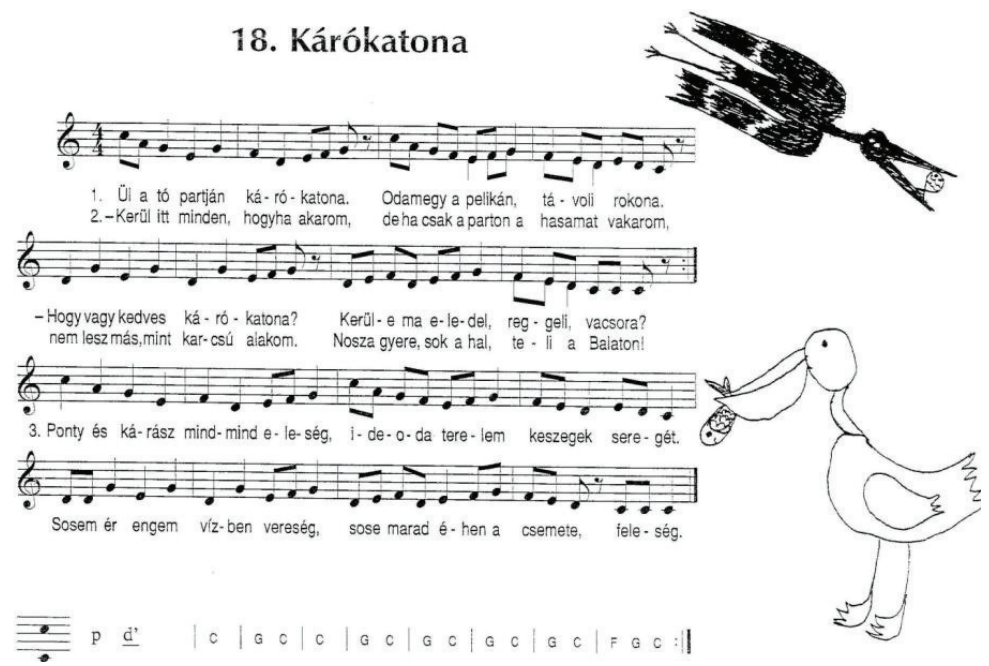

The music-rhythmic structure of the song is quite demanding, therefore it is recommended to be used with the school-preparatory group, as well as with younger schoolaged children.

Romanians live in almost forty settlements on the territory of the area of Banat which was from 1918 in the territory of Yugoslavia, and which today belongs to the Autonomous Province of Vojvodina in the Republic of Serbia. Some medieval sources tell us about the presence of Romanians' ancestors, in the period when they were developing as an nation, in the Pannonian Plain area when Hungarians were conquesting it. Latter, other sources mentioned the presence of Romanians in this part of Banat, usually as additional nonimportant information. Such sources can also be found from the period of the Turkish invasion of Banat, but they became especially numerous after the fall of Banat under Austrian rule (1716). Nowadays the number of Romanians in Banat - Autonomous Province Vojvodina is in constant decline, because of the low birth rate, emigration to the western countries, but also because of assimilation.

\section{Suggestion of music examples}

Example. Romanian national song with the games Drag mi-e jocul românesc andDragu mi-e badea ovcean (Lelea, 2005) 

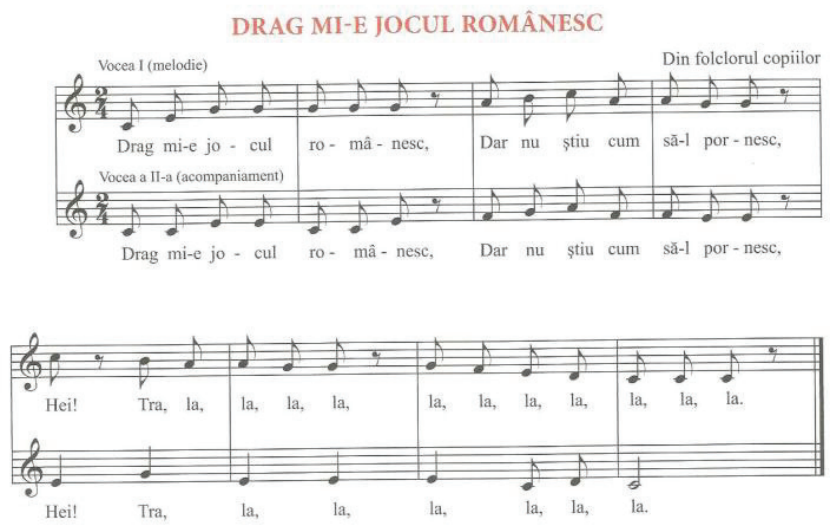

As in the previous example, the notary text of this song presupposes a performance in more voices which considering its structure (dominant accompaniment in the third), shouldn't be a problem. The text itself, the origin of the song in national dance and the inserted chorus starting with the letters la, la, la... give the preschool teacher the possibility to, after the song and literary text had been taught, use the example to set up a simple choreography through which the children can become familiar with the steps of Romanian national dance. The next example can have a similar application in practice. It originates from local Romanian folklore from the village Ovca near Belgrade.

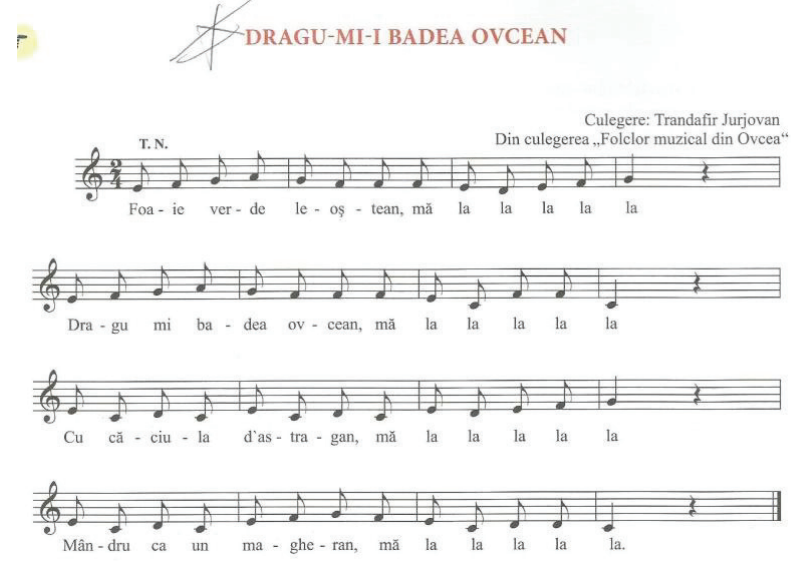

Example. Romanian ceremonial national song for the cycle of Easter holidays Lăzărelul (Lelea, 2009)

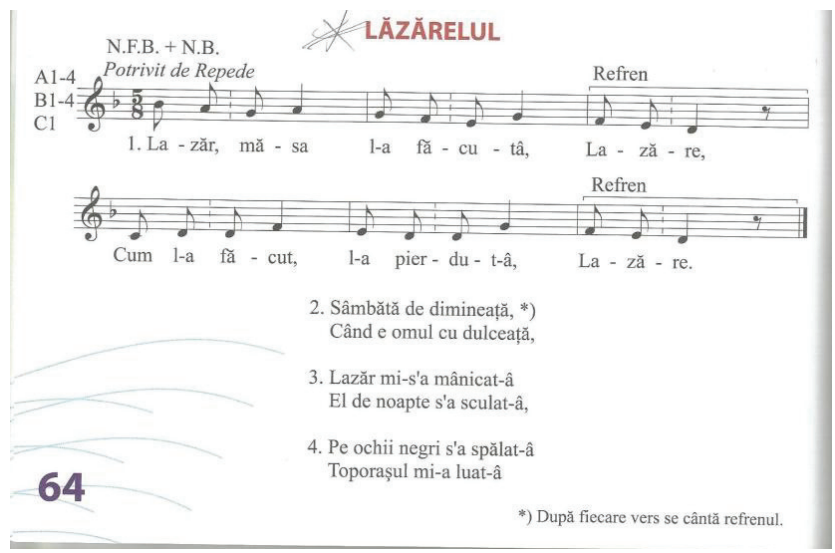


Known as lazarica, the song can be interesting for the familiarization of children with the specific rhythmic systems which are present in the national creative work and metric models which are not frequently present in classic repertoire for children. The simplicity of the text and melody can be an advantage for the children while they are in the process of decoding the unusual rhythmic and metric formulas. The song is a good suggestion for familiarizing the children with Romanian Easter traditions, i.e. with the traditions connected to Lazar's Saturday.

The settlement of Slovaks on the territory on part of the South Kingdom of Hungary (today's Vojvodina) started within the first phase of the Habsburg colonization which the Vienna nobility conducted in the $18^{\text {th }}$ century, after these territories were taken from the Turks. The first settlement of Slovaks in Backa was recorded in 1720 in Bajs, after which they settled Backi Petrovac (1740), Bezdan (1742) and Lalic (1760). In the next decades the colonization continued with the settlement of Kisac, Glozan and Pivnice. In the $19^{\text {th }}$ century it was continued in Kuplin (1812), Sibas (1814), Lalic (1760). The strongest center of Slovaks in Srem was Stara Pazova. In Banat the colonization started a bit latter than in Backa. The first settling was recorded in 1781 on the manor house of Isak Kis, where a Slovakian Aradac was founded. After this, they settled Coka, Pardanj and Hajducica. In the $19^{\text {th }}$ century they settled Supljaja, Banatski Dvor and Stari Lac, then Kovacica (1801-1802) and Padinu (18061809) on the territory of the Banat military border (German-Banat regiment no. 12 with the center in Palcevo). In the second half of the $19^{\text {th }}$ century they settle Voljovica, Ivanovo and Belo Blato.

\section{Suggestion of musical examples}

Example. Slovakian national song Pokapala na salaši slanin (Stankovićová-Kriváková, M., Nakićová, 2007: 20):

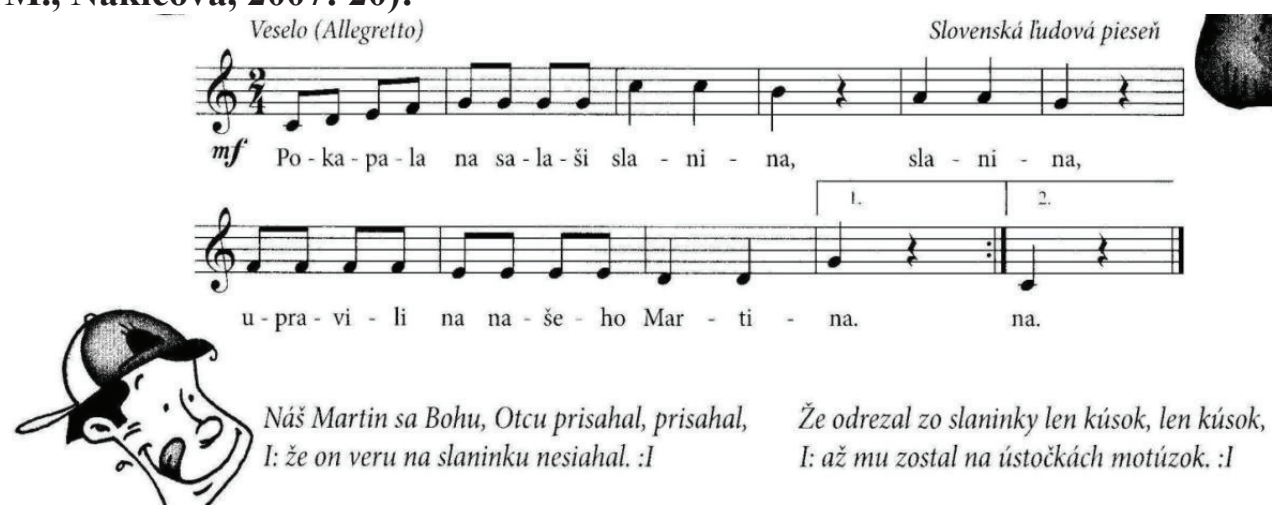

The song is intended to be performed with the older (if they have developed the voice range) and school-preparatory groups. It contains gradual melodic movement and quants and quintets which can according to need be applied in practice for the voice training exercises.

Example. Slovak children's song Mala som holúbka (Pavlovská, 1977: 128): 
Mala som holúbka

Ludová

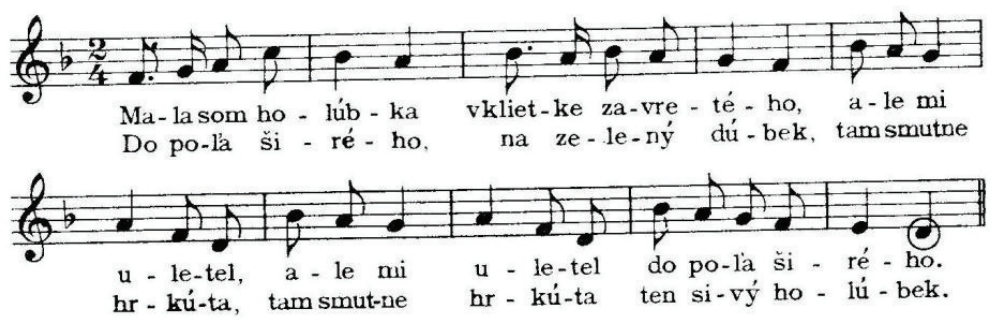

The song is intended to be used with the older and school-preparatory groups. It contains a specific rhythm - a dotted figure on the counting unit. Therefore it is suitable for creating music listening representations, and latter for the development of music literacy. Furthermore, the melody of the song contains a tone quant cord downwards with a jump to the fourth level which is repeated twice; therefore it is suitable for the practice of the given topic.

\section{Example. Slovakian national song Mám ja edom kabát nový (Stankovićová-Kriváková, M., Nakićová, 2007: 12):}

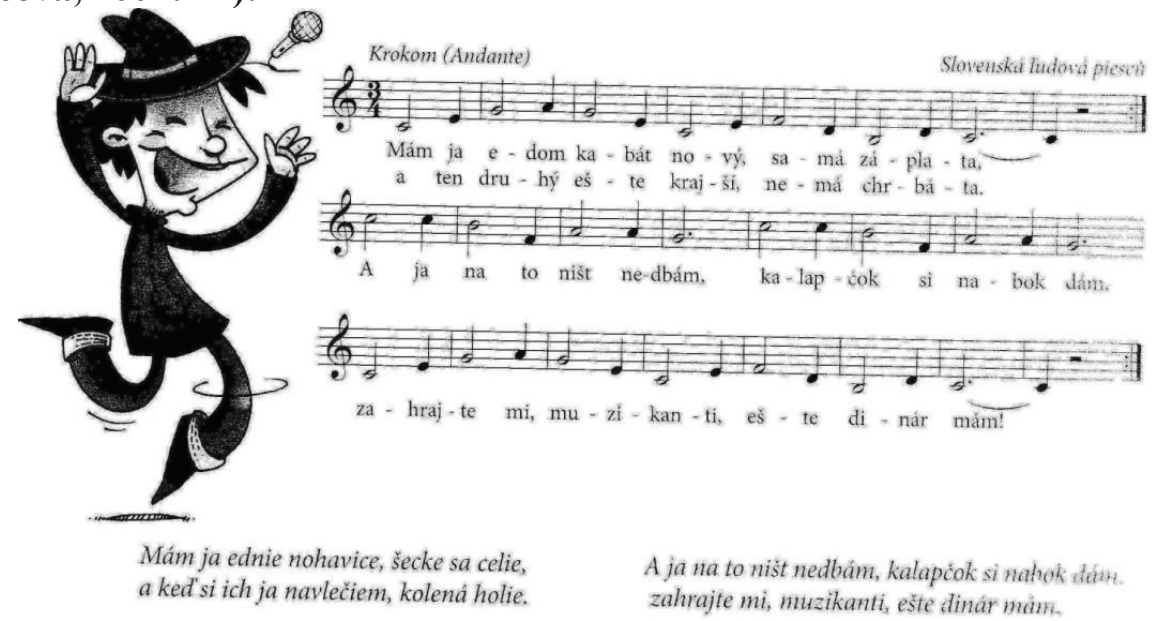

The song is suitable to be used with the school preparatory group but also with younger school children. Because of the specific type of text - three part, it is suitable for the creation of music-listening representations, and latter according to need for music literacy development, familiarization with musical genre of dance (waltz), as well as with the three part tact.

\section{Conclusion}

The continuality of a nation's folklore in the contemporary context can be secured only if the ones who value it and recognize its worth, manage to continually find ways to value folklore and in this age of unavoidable mercantilism, find a practical use for it. This collection of songs emerges from the idea to give the creative output created by the ethnic communities on the territory of Vojvodina a new dimension in the form of a didactic function and fulfill some of the goals of musical education of preschool children. This creative output has been created during the centuries and has been adapted to the times, feelings and social circumstances. With the implementation of national songs and dance children will become familiar with our cultural heritage but also the cultural heritage of other nations and peoples 
we live with. The songs and games can be used at the preschool and school age within educational institutions, but also within professional musical education.

\section{References:}

250 rokov života Slovákov vo Vojvodine (1996).Beograd: Zavod za udžbenike i nastavna sredstva; Novi sad: Spolok vojvodinských slovakistov.

Чинч, Е. (2012). Музичкахрестоматија. Вршац: Високашколаструковнихстудијазаваспитаче „МихаилоПалов“.

Činč, E. (2013). Muzičko vaspitanje sa metodikom. Vršac: Visoka škola strukovnih studija za vaspitače "Mihailo Palov".

Činč, E., Stolić, J. (2015). Organizovanje i rad sa dečijim muzičkim sastavima. Vršac: Visoka škola strukovnih studija za vaspitače „Mihailo Palov“.

Činč, E., Stolić, J., Planjanin-Simić, K. (2017). Application of Traditional Music at Preschool Age as a Factor of Presentation of One's Own Culture and Culture of Other Nations. Objavljen u zborniku radova sa treće internacionalne konferencije Education across Borders - Education and Research across Time and Space. ISBN 978-9989-100-50-5, COBISS.MK-ID 103722250, str. 1030-1037. Bitola: University „St. Kliment Ohridski“.

Đurić, R. (2006). Istorija Roma. Beograd.

Ђурковић-Пантелић, M.

Методикамузичкогваспитањадецепредиколскогузраста. Шабац: Висока школа за образовање васпитача.

Jankulov, B. (2005). Pregled kolonizacije Vojvodine u XVIII i XIX veku. Pančevo: Istorijski arhiv u Pančevu.

Jánský, P. (1994). Já, písnička 2. Cheb: Music Cheb.

Lelea, Ion. (2005). Cultura muzicală pentru clasa I a școlii elementare Beograd:ZUNS.

Lelea, Ion. (2009). Cultura muzicală pentru clasa a II- a școlii elementare Beograd:ZUNS.

Forrai, K. (1991). Ének az óvodában. Budapest: Editio Misoca.

Лекић, Ђ. (1955). Методика наставе певања у основној школи. Београд: Народна књига.

Maran, M. (2011). Rumuni u Vojvodini - Istorija, demografija, identitet Rumuna u vojvođanskim naseljima. Zrenjanin: Zavod za kulturu vojvođanskih Rumuna.

Pavlić-Mandić, R. (1979). Narodne igre. Sarajevo: Fakultet za fizičku kulturu Univerziteta u Sarajevu.

Pavlovská, O. (1977). Hudobná výchova. Bratislava: Opus.

Пописстановништва, домаћинставаистанова 2011. уРепублищиСрбији. Stanovništvo. Nacionalna pripadnost, Republički zavod za statistiku, Beograd, 2012. Dostupno na http://media.popis2011.stat.rs/2012/Nacionalna\%20pripadnost-Ethnicity.pdf

Popović, D. (1990). Srbi u Vojvodini, 1-3. Novi Sad: Matica srpska.

Правилникооштимосновамапредшколскогпрограма. (2006). Београд: СлужбенигласникРС - Просветнигласник.

Radičeva, D. (2000). Metodika komplementarne nastave solfeđa i teorije muzike. Novi Sad: Muzička akademija.

Radičeva, D. (2008). Uvod u metodiku nastave solfeđa. Novi Sad: Akademija umetnosti.

Rokai, P. i dr. (2002). Istorija Mađara. Beograd: Clio.

Stankovićová-Kriváková, M., Nakićová, D. (2007). Hudobná kultúra. Beograd: Zavod za udžbenike.

Súdiová, R., Súdi, J. (2005). Hudobná kultúra. Beograd: Zavod za udžbenike.

Стојановић, Г. (1996). Наставамузичкекултуре. Београд:

Заводзауибеникеинаставнасредства. 
Столић, J. (2014). Музичкеигреипокретузмузикуупериодупредшколскогузраста, одбрањенмастеррад. НовиСад: Академијауметности.

СтолићЈ.

(2015).

Значај, карактеристикеиврстемузичкихигаранапредиколскомузрасту, објављенуПедагошкастварност, НовиСад, бр.2/2015, УДК 37, ИССН 05534569, БИБЛИД 0553-4569, 61 (2015), 2, стр. 326-338.

Stolić, J., Činč, E., Maran, M. (2015).The Subcategories of Folklore Dance for Children as Didactic Games for Developing Musical Ability in the Preschool Period. Rad je objavljen u zborniku: International Scholarly and Scientific Research and Innovation, Waset, Amsterdam, 2015, str. 426-429.

Stolić, J. (2017). Dansurile populare ca păstrătoare ale culturii tradiţionale la vârsta preşcolară. Rad je objavljen u zborniku sa naučnog skupa Cultură tradiţională şi globalizare, Arad, izdavač: Editura Etnologică, Bucureşti, 2017, str. 182-193 , ISBN 978606-8830-22-3.

СтурзаМилић,

$\mathrm{H}$.

Моторниразвојифизичкаактивностдецејасленогипредиколскогузраста. В Вршац: Високашколаструковнихстудијазаобразовањеваспитача „МихаилоПалов”.

Špoljar, Z. (1927): Pjesmarica. Zagreb: Naklada knjižare St. Kugli.

Васиљевић, 3. (2003a). Музички буквар. Београд:Завод за уџбенике и наставна средства.

Васиљевић, М. (2003б). Народне мелодије с Косова и Метохије. Београд: Београдска књига.

Vasiljević, Z. (2006). Metodika muzičke pismenosti. Beograd: Zavod za udžbenike i nastavna sredstva.

Vasiljević, Z. (2008). Solfeđo-ritam - udžbenik za učenike III i IV razreda škole za osnovno muzičko obrazovanje. Knjaževac: AD „Nota“.

Vasiljević, Z. (2009). Solfeđo-ritam - udžbenik za učenike Vi VI razreda škole za osnovno muzičko obrazovanje. Knjaževac: AD „Nota“.

Vasiljević, Z. (2014). Solfeđo-ritam - udžbenik za učenike I i II razreda škole za osnovno muzičko obrazovanje. Knjaževac: DOO „Nota“. 